\title{
TEM MULHER NO SAMBA \\ A REPRESENTAÇÃO DA FIGURA FEMININA \\ NOS SAMBAS DAS DÉCADAS DE 1940-50
}

\author{
Larissa Archanjo Oliveira \\ Cilene Margarete Pereira \\ UNINCOR / FAPEMIG / CNPq
}

Em Acertei no milhar: samba e malandragem no tempo de Getúilio (1982), Claudia Matos observa que, nas décadas de 1930-40, pode-se reconhecer três grandes veios temáticos e estilísticos nas letras dos sambas: 0 apologético-nacionalista; aquele que ela identifica como samba malandro, centrado em um discurso que se afirma sobre a dubiedade, e o lírico-amoroso, no qual a figura feminina ganha espaço central. Em busca da identificação e análise dessas figuras femininas do samba, este artigo se deterá no exame de algumas letras das décadas de 1940-50, dando destaque às composiçōes de Herivelto Martins, Geraldo Pereira e Lupićnio Rodrigues.

PALAVRAS-CHAVES: Samba. Personagem Feminina. Malandro.

In Acertei no milhar: samba e malandragem no tempo de Getúlio (1982), Claudia Matos notices that, during the decades of 1930-40, three great thematic and stylistic veins in the samba lyrics can be recognized: the apologetic-nationalistic; one she identifies as sam-ba malandro, centering on a speech that states itself on the dubious; and the loving-lyrical, in which the female character gains central role. In search for identification and analysis of these female characters in the samba, this article will focus on the analysis of some songs from the decades of 1940-50, giving emphasis to the compositions of Herivelto Martins, Ge-raldo Pereira and Lupicínio Rodrigues.
\end{abstract}

KEYwORDS: Samba. Female character. Malandro.

Larissa Archanjo Oliveira é mestranda em Letras na Universidade Vale do Rio Verde de Três Corações.

Cilene Margarete Pereira é doutora em Teoria e História Literária pela Universidade Estadual de Campinas (UNICAMP) e professora coordenadora do Programa de Mestrado em Letras da Universidade Vale do Rio Verde de Três Corações. 
TEM MULHER NO SAMBA A REPRESENTAÇÃO DA FIGURA FEMININA NOS SAMBAS DAS DÉCADAS DE 1940-50

Larissa Archanjo Oliveira Cilene Margarete Pereira

INTRODUÇÃO

As influências rítmicas do samba, hoje um gênero musical (assim considerado desde 1917, ano de gravação do primeiro samba com letra e melodia, "Pelo Telefone"), chegaram ao Brasil, mais precisamente à Bahia, por meio dos negros escravos que as levaram para o Rio de Janeiro. Ao longo de sua constituição e consolidação, o samba sempre apresentou uma diversidade rítmica e de estilos, tendo o morro e as regiões centrais da cidade do Rio de Janeiro, das quais se destacam a Praça Onze e os bairros da Saúde, do Estácio e da Lapa, como lugar de sua origem carioca. Mas é somente ao final da década de 1920 que o gênero musical alcança verdadeiramente o Rio de Janeiro e o Brasil a partir de um movimento migratório paradoxal ao "subir e descer o morro", fixando nas encostas da cidade carioca seu lugar de origem mitológica. Esse movimento paradoxal se dá porque o chamado samba carioca não teria nascido nos morros, mas em bairros próximos da zona central do Rio. Segundo Heitor dos Prazeres:

A música era feita nos bairros: ainda não havia favelas, nem os chamados compositores do morro. O morro da Favela era habitado só pela gente que trabaIhava no leito das estradas de ferro (mineiros, pernambucanos e remanescentes da Guerra de Canudos). O samba original não tinha, portanto, nenhuma ligação com os morros. ${ }^{1}$

João da Baiana confirma o depoimento de Heitor dos Prazeres, ressaltando que o samba havia saído da cidade:

1 PRAZERES, Heitor dos apud SODRÉ, Muniz. Samba, o dono do corpo. 2. ed. Rio de Janeiro: Mauad, 1998, p. 69. 
Nós fugíamos da polícia e íamos para os morros fazer samba. Não haviam [sic] essas favelas todas. [...] Mas o samba não nasceu no morro, nós é que o levávamos, para fugir da polícia que nos perseguia. Os delegados Meira Lima e o Dr. Querubim não queriam o samba. ${ }^{2}$

Em depoimento, Donga lembra que o samba praticado no Rio "já existia na Bahia há muito tempo [...], mas foi aqui no Rio que se estilizou" ${ }^{3}$. Apesar de baiano e de raízes africanas, foi no Rio que o samba se consagrou e se afirmou como expressão de uma comunidade e uma nação, e o morro, escolhido como cenário principal desse acontecimento protagonizado por gente simples, de classes menos favorecidas, já que descendiam, em sua maioria, de escravos, conforme observa Sodré:

Os compositores são marceneiros, pintores de parede, serralheiros, fundidores, mecânicos, guardadores de automóveis, contínuos de repartições públicas ou de bancos, biscateiros, enfim membros do vasto conjunto de empregados ou subempregados que compõe as camadas de baixa renda da população carioca. ${ }^{4}$

Os sambistas do início do século passado não se dedicavam totalmente (e apenas) às composições, pois muitos tinham de se entregar a outros ofícios (dos quais muitos eram subempregos) como forma de subsistência mínima. $\mathrm{O}$ samba era, nesse momento, elemento continuador das origens (as raízes africanas) e promotor de uma expressão identitária, além de funcionar como compensação provisória à dura rotina diária. O samba, em sua função mais imediata, tem um caráter lúdico, promovendo, assim, um "território protegido das pressões externas, que é, simultaneamente, um território de prazer, com valores próprios, que procura preservar-se excluindo de si os fatores que representam opressão e desprazer" ${ }^{5}$. Nesse sentido, ele assume a função, segundo Claudia Matos, de "agente unificador e mantenedor de uma identidade sociocultural do grupo que o pratica", ganhando um "estatuto de patrimônio coletivo a ser cultuado e preservado" ${ }^{\circ}$.

\footnotetext{
2 BAIANA, João da apud MATOS, Claudia. Acertei no milhar. Samba e malandragem no tempo de Getúlio. Rio de Janeiro: Paz e terra, 1982, p. 28.

3 DONGA apud SODRÉ, Muniz. Samba, o dono do corpo, op. cit., p. 70.

${ }^{4}$ SODRÉ, Muniz. Samba, o dono do corpo, op. cit., p. 59. Em depoimento no mesmo livro, Pixinguinha ressalta: "O samba, você sabe, era mais cantado nos terreiros, pelas pessoas muito humildes. Se havia uma festa o choro era tocado na sala de visitas e o samba só no quintal para os empregados." (p. 79)

${ }^{5}$ MATOS, Claudia. Acertei no milhar, op. cit., p. 31.

${ }^{6}$ ibidem, p. 31.
} 
Considerando o espaço social do samba, destaca-se a casa de Tia Ciata ${ }^{7}$, local de comunhão de sambistas e artistas e também de classes sociais. A casa representava metonimicamente a estrutura social do Brasil das primeiras décadas do século $X X$ :

\begin{abstract}
Metáfora viva das posições de resistência adotadas pela comunidade negra, a casa continha os elementos ideologicamente necessários ao contato com a sociedade global: "responsabilidade" pequeno-burguesa dos donos (o marido era profissional liberal valorizado e a esposa, uma mulata bonita e de porte gracioso); os bailes na frente da casa (já ali se executavam músicas e danças mais conhecidas, mais "respeitáveis"), os sambas (onde atuava a elite da ginga e do sapateado) nos fundos; também nos fundos, a batucada - terreno próprio dos negros mais velhos, onde se fazia presente o elemento religioso $[\ldots]{ }^{8}$
\end{abstract}

O epíteto tia, que acompanhava o nome de Ciata, dava-se porque, "naquela região, famosos chefes de culto (ialorixás, babalorixás, babalaôs), conhecidos como tios e tias, promoviam encontros de dança (samba) à parte dos rituais religiosos (candomblés)" ${ }^{9}$.

\title{
O SAMBA E SUAS GERAÇÕES
}

Em Acertei no Milhar. Samba e malandragem no tempo de Getúlio, Claudia Matos aponta a existência de três gerações do samba carioca, sendo a terceira uma continuidade das inovações empreendidas pela segunda. A primeira geração, datada do início do século XX, era a dos "sambistas primitivos", dos quais se destacavam Sinhô, Donga, João da Bahiana, Caninha e Pixinguinha, este no choro. Esses sambistas concentravam-se em torno da casa da baiana Ciata e praticavam um "samba amaxixado", próximo ao Lundu. É originário dessa "escola primitiva" aquele considerado o primeiro samba gravado, "Pelo

\footnotetext{
7 "Nascida em Salvador em 1854, presumidamente de escravos forros, Tia Ciata chegou ao Rio de Janeiro em 1876. Lá, casou-se com João Batista da Silva, também negro e baiano, que em Salvador chegara a cursar dois anos da Faculdade de Medicina e mais tarde conseguiu emprego no gabinete do chefe da polícia da capital federal - e, de acordo com o depoimento de seu neto, isso foi possível graças à intervenção dos orixás de Tia Ciata, que teriam curado a perna doente do então presidente da República, Wenceslau Brás!" SANDRONI, Carlos. Feitiço decente. Transformações do samba no Rio de Janeiro (1917-1933). 2. ed. Rio de Janeiro: Zahar, 2012, p. 104.

${ }^{8}$ SODRÉ, Muniz. Samba, o dono do corpo, op. cit., p. 15.

9 ibidem, p. 14.
} 
Telefone", de $1916 .{ }^{10}$ Muniz Sodré observa que nos versos da canção, sobretudo aqueles que faziam referência ao comportamento da polícia no idos de 1916 - o ensaísta refere-se aos versos "O chefe da Polícia/ pelo telefone/ manda avisar/ que na Carioca/ tem uma roleta/ para se jogar" —, fixava "uma das principais características do samba carioca: a letra como crônica do Rio de Janeiro e da vida nacional." ${ }^{11}$

Os versos referidos, apesar de não originais do samba, foram incorporados depois.

Segundo Almirante, tal versão teria nascido de um despacho e uma reportagem. O despacho foi publicado pelo chefe da polícia, Aurelino Leal, em 30 de outubro de 1916, determinando a seus subordinados que informassem imediatamente, pelo telefone, a apreensão de material de jogo. Esse despacho teria motivado uma reportagem do jornal $A$ Noite, que para desmoralizar Aurelino instalou uma banca em pleno Largo da Carioca. A partir dessa reportagem é que teria sido feita uma paródia da música já existente, mais tarde incorporada à canção. ${ }^{12}$

A segunda geração de sambistas, centrada em meados da década de 1920, ficou conhecida como "samba do Estácio", justamente por ser este bairro local de seus principais compositores: Ismael Silva, Nilton Bastos, Bide, Mano Rubem, Mano Edgar, Baiaco e Brancura. A respeito dessa geração, Claudia Matos observa que

A nova modalidade de samba que eles começaram a fazer na década de 20 se amoldava melhor às necessidades carnavalescas, naquele tempo em que o carnaval se popularizava, tornava-se mais amplo e movimentado, e também, num certo sentido, mais brasileiro e mestiço. ${ }^{13}$

Em entrevista a Sérgio Cabral, Ismael Silva explica a diferença do "samba do Estácio" em oposição ao que se vinha praticando:

10 "Pelo Telefone" é um "partido alto", tipo de samba feito coletivamente (Donga, Sinhô, João da Baiana, Tia Ciata, entre outros seriam seus compositores), mas foi registrado por Donga, com letra do jornalista Mauro de Almeida, na Biblioteca Nacional em 30 de maio de 1917.

${ }^{11}$ SODRÉ, Muniz. Samba, o dono do corpo, op. cit., p. 43.

${ }_{12}^{12}$ CALDEIRA, Jorge. A construção do samba. São Paulo: Mameluco, 2007, s/p.

${ }^{13}$ MATOS, Claudia. Acertei no milhar, op. cit., p. 40. Tal nota é também dada por Carlos Didier ao observar que os sambas dos compositores do Estácio distinguiam-se "daqueles consagrados por Sinhô pelo menos por sua pulsação rítmica mais complexa. Enquanto estes guardavam vestígios de antigos maxixes, aqueles sambas que vinham do Estácio [se caracterizavam] pela agregação de mais de uma célula rítmica à marcação." DIDIER, Carlos apud SANDRONI, Carlos. Feitiço decente, op. cit., p. 34. 
É que quando comecei, o samba da época não dava para os grupos carnavalescos andarem na rua, conforme a gente vê hoje em dia. O estilo não dava para andar. Eu comecei a notar que havia essa coisa. O samba era assim: tan tantan tan tantan. Não dava. Como é que um bloco ia andar na rua assim? Aí, a gente começou a fazer um samba assim bum bum paticumbumprugurudum. ${ }^{14}$

Para Matos, esse novo ritmo, dado pelos sambistas do Estácio, mostrava que o samba ganhava "ginga, flexibilidade e mobilização simultâneas"15. Esse "samba carnavalesco", mais sincopado e malicioso, feito para o acompanhamento de cordões e blocos, tratava de assuntos cotidianos, geralmente com alguma comicidade, transformando, muitas vezes, o trágico ou sério em motivo de riso. Mais tarde, precisamente em 1927, surge a primeira Escola de Samba, Deixa Falar, adotando o novo ritmo de samba, mais adequado ao acompanhamento dos membros da agremiação.

Em "Se você jurar" (1931), samba de Ismael Silva e Nilton Bastos em parceria duvidosa com Francisco Alves ${ }^{16}$, a letra aborda, de modo bem humorado, fatos corriqueiros da vida de um malandro em "regeneração". A sabedoria malandra ("Agora estou sabido") está em reportar o sucesso de sua regeneração ao comportamento feminino, sempre marcado, sobretudo no samba, como falso:

Se você jurar que me tem amor

Eu posso me regenerar

Mas se é para fingir, mulher

A orgia assim não vou deixar

Muito tenho sofrido

Por minha lealdade

Agora estou sabido

Não vou atrás de amizade

A minha vida é boa

Não tenho em que pensar

\footnotetext{
${ }^{14}$ SILVA, Ismael apud MATOS, Claudia. Acertei no milhar, op. cit., p. 40.

${ }^{15}$ MATOS, Claudia. Acertei no milhar, op. cit., p. 41.

16 "Em 1927, [Ismael Silva] foi visitado por Bide quando estava internado no Hospital da Gamboa que lhe levou a proposta de Francisco Alves de comprar seu samba 'Me faz carinhos'. A partir daí, o grande cantor das rádios passou a comprar algumas músicas de sua autoria, grande parte composta em parceria com Nilton Bastos. No fim da década de 1920, fez um acordo com Francisco Alves, que permitia ao cantor gravar composições suas e constar como autor mediante pagamento prévio. Esse 'comércio' de sambas era prática comum nos anos de 1920 e 1930. Além dele, Noel Rosa, Cartola, Nélson Cavaquinho e outros venderam sambas." Dicionário Cravo Albin de Música Popular Brasileira. Ismael Silva.
} 


\author{
Por uma coisa à toa \\ Não vou me regenerar \\ A mulher é um jogo \\ Difícil de acertar \\ E o homem como um bobo \\ Não se cansa de jogar \\ O que eu posso fazer \\ É se você jurar \\ Arriscar a perder \\ Ou desta vez então ganhar
}

É interessante observar que a mulher (e a capacidade redentora de seu amor) é, nesta samba, descrita de maneira bem negativa, pois, além de ser "coisa à toa", é ainda comparada ao jogo no qual o homem lança sua sorte para perder ou ganhar. Diante de tamanha incerteza, mais vale, para o eu lírico da canção, permanecer em sua vida malandra: "A orgia assim não vou deixar". Importante ressaltar que a construção melódica do samba, bastante dançante e sincopado, casa perfeitamente com sua letra, promovendo uma solução rítmica ideal para o tema do malandro em processo de regeneração.

A partir da década de 1930, tem-se o que se pode chamar de "terceira geração do samba", aquela já inserida na comercialização do gênero, entendido como produto da indústria cultural. É nesse momento que o samba se difunde como veículo de expressão nacional. Muniz Sodré observa a distinção entre o chamado "samba tradicional", aquele feito na roda de samba a partir das improvisações sobre uma primeira parte ${ }^{17}$, e o "samba produto cultural", organizado para a forma do disco e que, portanto, "impõe peças prontas e acabadas" $^{18}$. Nessa geração, dada sobretudo a importância da Rádio como veículo de difusão cultural, grandes compositores se afirmavam, dentre os quais se destacam Noel Rosa, Wilson Batista, Herivelto Martins, Geraldo Pereira, Ataulfo Alves e Ary Barroso, estes três últimos mineiros que fizeram sua carreira musical no Rio de Janeiro.

\footnotetext{
17 “[...] antigamente, os sambistas compunham só uma primeira parte da canção (samba de primeira parte), reservando à segunda um lugar de resposta social: ora a improvisação na roda de samba, ora o improviso dos diretores de harmonia na hora do desfile da escola." SODRÉ, Muniz. Samba, o dono do corpo, op. cit., p. 58.

18 ibidem, p. 58. Sodré já identifica um processo inicial de industrialização do samba na gravação de "Pelo telefone", considerando que "da canção folclórica (de produção e uso coletivos, transmitida por meios orais) transforma-se em música popular, isto é, produzida por um autor (indivíduo conhecido) e veiculada num quadro social mais amplo." (p. 40)
} 


\section{O SAMBA DA TERCEIRA GERAÇÃO: TEMAS E ESTILOS}

Considerando essa divisão entre gerações, Claudia Matos ressalta que, nas décadas de 1930 e 1940, pode-se reconhecer e definir três grandes "veios temáticos e estilísticos" nos sambas: o lírico-amoroso, tendo a figura feminina como impulsionador das canções; o apologético-nacionalista e o que ela identifica como "samba malandro", centrado em um discurso que sempre se afirma sobre a dubiedade. ${ }^{19}$ A figura do malandro, no entanto, já aparece no início da década de 1920, visto que "a malandragem carregaria consigo a ideologia da negação moral e da conduta exemplar, seguindo a valorização do prazer, da dança, do sexo e da bebida."20

Essa divisão temática e estilística proposta por Matos torna possível identificar que, associado aos veios lírico-amoroso e ao "samba malandro", um espaço bastante amplo é reportado à mulher, que encena, nas composições de sambas, um repertório variado. Em busca da identificação e análise dessas figuras femininas do samba, este artigo se deterá na análise de algumas canções das décadas de 1940-50, dando destaque a "Cabelos brancos" (1949), de Herivelto Martins e Marino Pinto; "Pedro do Pedregulho" (1950), de Geraldo Pereira; "Se acaso você chegasse" (1956), de Lupicínio Rodrigues. Para compor argumentos em relação aos tipos femininos aí encontrados, faremos, quando necessário, comentários a respeito de outras canções dos respectivos compositores.

Em "Sossega leão! Algumas considerações sobre o samba como forma de cultura popular", Manoel Berlinck apresenta uma análise de algumas letras de sambas observando a predominância de três tipos femininos, as quais ele denominou de "doméstica", "piranha" e "onírica"21. Essa tipologia feminina, bastante esquemática, foi sintetizada por Ruben Oliven em, "A mulher faz e desfaz o homem", da seguinte maneira:

\footnotetext{
A primeira seria a mulher submissa e passiva, centrada no lar, a serviço do homem, que ordena as relações sociais e compõe o cotidiano. A segunda é a mulher de vida fácil, que satisfaz o homem em sua boemia, mas se caracteriza pela traição e por descontrolar e desorganizar as relações sociais. A terceira
}

\footnotetext{
${ }^{19}$ MATOS, Claudia. Acertei no milhar, op. cit., p. 45.

${ }^{20}$ CAVALCANTI, Luciano Marcos Dias. Música popular brasileira e poesia. A valorização do "pequeno" em Chico Buarque e Manuel Bandeira. Belém: Paka-Tatu, 2007, p. 26.

${ }^{21}$ BERLINCK, Manoel Tosta. Sossega leão! Algumas considerações sobre o samba como forma de cultura popular. Contexto, São Paulo, n. 1, p. 103, nov. 1976.
} 
representa uma mulher inexistente, construída com expressões românticas. ${ }^{22}$

Essa tipologia feminina apresentada por ambos os sociólogos, mesmo apresentando problemas diante da complexidade da mulher representada no samba, pode nos ajudar a compreender aspectos de sua caracterização, sobretudo considerando composições representativas do eixo lírico-amoroso de nosso cancioneiro popular, na qual a figura feminina se constrói mediante sua relação com o homem.

\section{HERIVELTO MARTINS E AUSÊNCIA (PRESENÇA) FEMININA}

Parte importante do cancioneiro de Herivelto Martins deve-se à sua atribulada vida amorosa, sobretudo ao seu casamento com Dalva de Oliveira, marcado por conflitos e traições. Foi a partir de um fato real que Herivelto compôs o samba "Cabelos brancos" (1949). ${ }^{23}$ A história da canção foi contada pelo próprio compositor ${ }^{24}$ : separado de Dalva, Herivelto estava em São Paulo. Numa quitanda, ouviu algumas senhoras falando mal de Dalva. Certo de que as ofensas dirigiam-se a ele, pensou, "respeite ao menos meus cabelos brancos, não fale dessa mulher perto de mim", mesmo não tendo, na época, um fio branco sequer. Surgia aí a primeira parte da canção que só fora finalizada, em parceria com Marino Pinto, na mesa de um bar.

\begin{abstract}
Não falem desta mulher perto de mim Não falem pra não lembrar minha dor Já fui moço, já gozei a mocidade Se me lembro dela me dá saudade Por ela vivo aos trancos e barrancos Respeitem ao menos os meus cabelos Brancos
\end{abstract}

Ninguém viveu a vida que eu vivi Ninguém sofreu na vida o que eu sofri As lágrimas sentidas

Os meus sorrisos francos

${ }^{22}$ OLIVEN, Ruben George. A mulher faz e desfaz o homem. Ciência Hoje, Rio de Janeiro, v. 7, n. 37, p. 57, nov. 1987.

${ }^{23}$ "O samba foi lançado primeiro pelo conjunto Quatro Ases e um Coringa na Odeon, mas teve regravações de Nelson Gonçalves, Sílvio Caldas, Roberto Silva e outros". Dicionário Cravo Albin de Música Popular Brasileira. Herivelto Martins.

${ }^{24}$ Ensaio. Herivelto Martins. Dir. Fernando Faro. São Paulo: TV Cultura, 1990. 


\author{
Refletem-se hoje em dia \\ Nos meus cabelos brancos \\ E agora em homenagem ao meu fim \\ Não falem desta mulher perto de mim
}

No primeiro verso da canção o eu lírico já expõe um sentimento de rejeição da mulher: "Não falem desta mulher perto de mim". É importante notar o uso do pronome demonstrativo "desta" reforçando, por um lado, a proximidade da mulher, isto é, que ela ainda permanece próxima de seus sentimentos; por outro, o modo como isso ajuda a descaracterizá-la, sobretudo porque acompanhado do substantivo mulher. A ex-mulher amada adquire, assim, um sentido paradoxal, afirmando sua permanência e ausência ao mesmo tempo. Nos versos seguintes, o eu lírico explica o paradoxo na construção da imagem feminina, pois "esta mulher" o lembra da dor e do amor: "já fui moço já gozei a mocidade/ se me lembro dela me dá saudade/ por ela vivo aos trancos e barrancos/ respeitem ao menos meus cabelos brancos". Num tom saudosista, reforça que já fora feliz com "esta mulher" que, hoje, já não existe mais; o sofrimento do eu lírico decorre da ausência da amada que se prolonga temporalmente, na canção, pela imagem contida na expressão "respeite os meus cabelos brancos".

Outro aspecto importante nos dois primeiros versos diz respeito à negativa dupla ("Não falem... / Não falem...") que acaba por reforçar a necessidade do eu lírico de falar sobre "esta mulher", já que na sequência dos versos há uma exposição dos efeitos femininos no homem, a ponto de fazê-lo viver "aos trancos e barrancos".

A segunda parte da canção ressalta, de maneira bastante lacunar, a trajetória do casal, sempre a partir da experiência de encontro/desencontro do eu lírico: "Ninguém viveu a vida que eu vivi/ ninguém sofreu na vida o que eu sofri/ As lágrimas sentidas/ os meus sorrisos francos/ refletem-se hoje em dia/ nos meus cabelos brancos". Em outras palavras, a imagem do eu lírico, de "sorrisos francos" e "cabelos brancos", é resultado final da desilusão amorosa promovida por "esta mulher". De algum modo, é ela quem ajuda a construir a imagem masculina, sendo responsável, segundo as acusações do eu lírico, pelo seu sofrimento e envelhecimento (precoce) - transformação moral e física do homem. Não é difícil perceber que, mesmo diante de uma desconstrução masculina dupla (o homem se descompõe assumindo suas fragilidades emocionais, e a mulher tem relação direta com essa imagem masculina presente), 
"esta mulher" é elemento de organização da vida masculina, visto que sem ela o que resta é a tentativa (o pedido) de silêncio ("Não falem"), encarada, no final da canção, como uma espécie de homenagem póstuma a esse homem que "morre": "E agora em homenagem ao meu fim/ não falem dessa mulher perto de mim".

O samba "Sem ela" (1943), também de Herivelto Martins, explora figura feminina relacionada, aqui, à do "malandro" que fica indeciso entre a vida de solteiro (e de amizades) e à de um amor estável.

\author{
Eu era tão diferente \\ Sem ela \\ E ela me apareceu de repente \\ Agora eu vivo com ela contente \\ Mas a minha mudança \\ Quem é que não sente \\ Quem é que não sente \\ Os amigos me aconselham \\ Manda essa mulher embora \\ Ela já soube \\ Coitadinha como chora \\ Sem eles não vivo bem \\ Sem ela muito pior \\ Mas contudo \\ Viver pra ela é melhor
}

Mesmo que, ao final da canção, o eu lírico assuma a relação amorosa, dizendo que "viver pra ela é melhor", há, aqui, uma cisão difícil de ser contornada, pois "sem eles [os amigos] não vivo bem". Em resposta aos conselhos dos amigos ("Manda essa mulher embora"), a figura feminina encena um papel básico (e esperado): "Ela já soube/ Coitadinha como chora". É interessante pontuar que ao assumir essas fragilidades emocionais, sempre associadas ao mundo feminino, a mulher passar a controlar a situação, mantendo, mesmo depois das insistências masculinas ("Mas a minha mudança/ Quem é que não sente/ Quem é que não sente"), o eu lírico preso a ela e a suas exigências ("Viver pra ela é melhor"). Tal estratégia feminina estaria inscrita naquilo que Maria Lúcia Rocha-Coutinho entende como parte de um processo de socialização da mulher. Ela esclarece que foi dentro do "mundo sentimentalizado da casa" que as mulheres exerceram sua autoridade, buscando utilizar "como armas, muitas vezes, exatamente aquelas virtudes que se esperava de 
seu sexo: a fraqueza, quase sempre aparente, a doçura, a indulgência, a abnegação. ${ }^{25}$ Neste processo de socialização, as mulheres foram treinadas a utilizar seus aspectos emocionais, visíveis na própria fala e nos modos de interação com o outro, para convertê-los em vantagens diante da "autoridade" do sexo masculino.

Neste samba de Herivelto é importante notar que o homem não celebra o amor como algo harmônico (viver com ela, por exemplo), mas como uma obrigatoriedade vital (viver pra/por ela). Em "Sem ela", a figura feminina aparece como regularizadora da vida masculina, capaz de transformar o sujeito com ares de malandro: "Eu era tão diferente/ Sem ela".

\title{
GERALDO PEREIRA E A MULHER “CONSTRUTORA”
}

Em "Pedro do Pedregulho" (1950), samba-canção composto pelo mineiro Geraldo Pereira, temos um eu lírico que narra a trajetória de conversão da personagem Pedro dos Santos, um malandro valentão morador do Morro do Pedregulho.

\author{
Pedro dos Santos vivia no Morro do Pedregulho \\ Quebrando boteco, fazendo barulho \\ Até com a própria polícia brigou \\ Vivia do jogo e quando perdia só mesmo muamba \\ Rasgava pandeiro, acabava com o samba \\ Parece mentira, Pedro endireitou. \\ Estelinha, orgulho do morro, mulher disputada \\ Que quando ia ao samba saía pancada \\ Ao Pedro dos Santos deu seu grande amor \\ E ele trocou o revólver que usava, fingindo embrulho \\ Por uma marmita \\ E sobe o Pedregulho \\ De noite, cansado do seu batedor.
}

A caracterização desordeira de Pedro dos Santos é típica do malandro brigão - tal como era, segundo dizem, o próprio Geraldo Pereira. A organização do mundo masculino dá-se por meio da mulher, mas não de qualquer mulher e, sim, Estelinha, "orgulho do morro, mulher disputada/ Que quando ia ao

\footnotetext{
${ }^{25}$ ROCHA-COUTINHO, Maria Lúcia. Tecendo por trás dos panos. A mulher brasileira nas relações familiares. Rio de Janeiro: Rocco, 1994, p. 74.
} 
samba saía pancada". Estelinha, a estrela ordenadora do mundo de Pedro, é uma das figuras femininas da galeria de Geraldo Pereira que conota certa complexidade, pois se pode ser associada à mulher "doméstica" por ordenar as relações sociais e compor o cotidiano do homem - trazer uma regularidade - , não é de modo algum submissa e aprisionada ao lar; prova disso é o espaço social que ocupa no morro do Pedregulho, a roda de samba. Assim como outras mulheres nas canções de Geraldo, Estelinha é também desejada pelos homens, mas sua escolha amorosa repercute na regeneração do malandro que troca o revólver, instrumento de violência e poder, pela marmita, objeto de contenção e subordinação. O processo de regeneração de Pedro dos Santos simboliza, na linguagem do malandro, sua imobilização (tornar-se otário) ${ }^{26}$, transformando-se em mais um na massa de manobra de exploração capitalista. Em outras palavras, o que faz Pedro dos Santos negar a vida de malandro e se atirar na de assalariado é a necessidade de construir uma vida modelar e padrão com Estelinha. Sustentar a mulher com honestidade é, nesse sentido, índice de uma masculinidade correta e ordeira, já observado por Geraldo Pereira no samba "Bolinha de papel", de 1945:

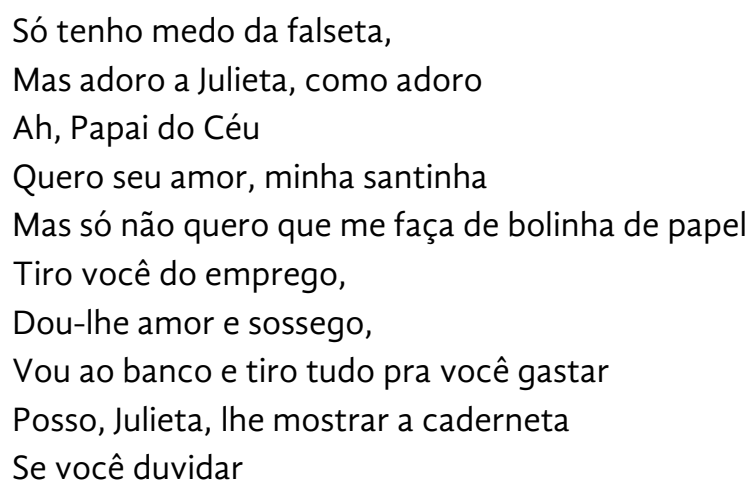

Apesar do medo de ser traído/abandonado por Julieta, o eu lírico está disposto a dar-lhe uma vida tranquila e confortável, que inclui dinheiro para seus luxos ("Vou ao banco e tiro tudo para você gastar") e seu aprisionamento no lar ("Tiro você do emprego"). A troca, segundo a concepção masculina, é bas-

\footnotetext{
${ }^{26}$ Essa oposição é bem marcada no samba e na expressão popular. "Bonde de São Januário", parceria entre Wilson Batista e Ataulfo Alves, "tinha uma letra de exaltação ao trabalho e que foi muito cantado no carnaval [de 1940], seja com a letra original, seja com a alteração promovida pela população que em lugar de cantar 'O bonde São Januário/ Vai levar mais um operário/ Sou eu que vou trabalhar', passou a cantar: 'O bonde São Januário vai levar mais um otário/ Pra ver o Vasco apanhar'." Dicionário Cravo Albin de Música Popular Brasileira. Wilson Batista.
} 
tante justa. Para dar seu nome a Julieta, o eu lírico de "Bolinha de papel" precisa trancá-la em casa, extinguindo o espaço da rua. O que temos em "Bolinha de papel" é a promoção (e prolongamento) de um visível antagonismo entre os gêneros, fruto de um discurso (erudito e também popular) que sempre afirmou a diferença entre os sexos tratando-os como "duas espécies" dotadas de qualidades distintas e de aptidões específicas, não por acaso, opostas:

Os homens estão do lado da razão e da inteligência que fundam a cultura; a eles cabe a decisão, a ação e, consequentemente, a esfera pública. As mulheres se enraízam na Natureza; elas têm o coração, a sensibilidade, a fraqueza também. $^{27}$

Dentro dessa perspectiva "segregadora" impõe-se, portanto, uma nítida divisão entre as atividades destinadas à mulher (ligadas todas ao território doméstico) e as funções estritamente masculinas (associadas ao espaço público).

Em "Bolinha de papel", a sugestão do aprisionamento de Julieta traz um elemento bastante importante, pois o eu lírico quer tirá-la do emprego para dar-lhe "amor e sossego". Sem desconsiderar o componente amoroso, é o termo "sossego" que nos chama a atenção, pois revela, de modo implícito, como o trabalho assalariado é um agente eficaz de alienação e desprazer.

E o que é, no caso, o desprazer? Para o proletário, são [...] as carências materiais da vida [...]. Quais são os fatores associados ao desprazer? O trabalho mal remunerado e excessivo, a enorme defasagem entre as classes sociais, as relações desequilibradas e injustas entre o capital e a força de trabalho. ${ }^{28}$

Considerando a época da canção, 1945, duas perguntas podem ser feitas: Que tipo de trabalho teria Julieta? O que essa deserção feminina do mundo do trabalho significa num momento em que há um culto à ideologia do trabalho pelo Estado Novo?

A indústria têxtil foi um dos ramos que se desenvolveu, no Brasil, absorvendo a mão de obra feminina, sobretudo nas décadas de 1930 e $40 .^{29}$ Não

${ }^{27}$ PERROT, Michelle. As mulheres ou os silêncios da história. Trad. Viviane Ribeiro. Bauru: EDUSC, 2005, p. 268-269.

${ }^{28}$ MATOS, Claudia. Acertei no milhar, op. cit., p. 31.

${ }^{29}$ O samba "Três apitos" (1933), de Noel Rosa, tem presente uma mulher que trabalha como tecelã. 
seria errado pensar que Julieta possa ser uma trabalhadora da indústria têxtil (ou mesmo uma empregada doméstica ${ }^{30}$ ) devido a dois fatores: em primeiro lugar, à mulher não eram dadas condições de educação que proporcionassem cargos que fugissem ao trabalho manual ou burocrático menor; em segundo, há a necessidade do trabalho para o sustento da personagem. A canção, ao ilustrar a possibilidade de renúncia à ocupação profissional, promove, de maneira bem sutil - não podemos nos esquecer de que temos um eu lírico masculino oferecendo seu amor à mulher em troca de dedicação ao lar - a desvalorização do trabalho (em pleno Estado Novo!), mostrando-o como algo penoso e árduo para mulher (quiçá para todos) ainda mais em se tratando de uma atividade de esforço físico. Em "Três apitos", Noel revela outro aspecto da questão, pois o trabalho pode significar para a mulher (e para seu companheiro) algo até humilhante, já que ela deve se submeter "às ordens" (e talvez ao assédio) de algum "gerente impertinente".

Em "Pedro do Pedregulho", o aprisionamento feminino sugerido em "Bolinha de papel" não fica claro, pois o que está em evidência na canção é a imagem masculina regenerada pelo amor da mulher ${ }^{31}$, isto é, o modo como Pedro deixa de pertencer à rua como mundo da desordem, inserindo-se em outra realidade, na qual o espaço da rua é apenas lugar de subsistência/humilhação do trabalhador. Por outro lado, a relação cotidiana entre Estelinha, "o orgulho do morro", e Pedro, o ex-malandro, pode se assemelhar à vivida pelas personagens de "Quando ela samba" (1942), de Geraldo Pereira e J. Portela.

\author{
Quando minha cabrocha \\ Entra no samba que tem na favela \\ Com sua saia de roda \\ Verde e amarela \\ Vejo que todos desejam sambar \\ Sambar com ela \\ Eu não sei qual o mistério \\ Que há nas cadeiras dela \\ Quando o samba é bem cantado
}

\footnotetext{
${ }^{30}$ A personagem apareceria no samba "Ministério da economia" (1951), composto por Geraldo e Arnaldo Passos, no qual o desejo do eu lírico é, por meio da nova realidade sugerida pela criação do ministério, tirar sua companheira da vida dura de doméstica da Zona Sul: "A vida estava tão difícil/ Que eu mandei a minha nega bacana/ Meter os peitos na cozinha da madame/ Em Copacabana."

${ }^{31}$ Não por acaso, o nome Estela, além de significar Estrela (aquela que orienta a vida de Pedro), é também lápide, simbolizando a morte do malandro e o nascimento de um novo homem, inserido no sistema capitalista.
} 


\author{
Batem palmas e é bisado \\ Somente pra minha cabrocha sambar \\ E quando a vejo cantando e sambando \\ Ao som do pandeiro \\ Eu juro, me sinto mais brasileiro
}

$\mathrm{Na}$ canção, o casal vive o momento do samba de modo harmônico: o homem vendo e admirando, exuberante, a companheira sambar. A relação não deixa evidente nenhum descompasso que possa associar a figura feminina à "doméstica", submissa e aprisionada no lar, ou àquela que decompõe a vida moral do homem ao revelar sua sexualidade. Na verdade, a canção parece promover a junção entre estas duas instâncias femininas, relativizando o valor moral atribuído a cada uma delas: a cabrocha sedutora de saia verde amarela que samba é também a companheira que constrói o cotidiano masculino, organizando-o, mas que não deixa de circular pelo espaço social do samba e despertar o desejo alheio ("Vejo que todos desejam sambar/ Sambar com ela"). Talvez a imagem construída aí seja a da idealização do samba como elemento de harmonização entre todos e de construção de brasilidade. Nesse sentido, o argumento de Claudia Matos sobre a canção "Ganha-se pouco mas é divertido" (1940), de Wilson Batista e Cyro de Souza ${ }^{32}$, pode ser utilizado na análise de "Quando ela samba". Segundo a autora,

\footnotetext{
Apesar da tendência à idealização patente nestes versos, observa-se que eles configuram uma verdade particular à comunidade da favela e do samba, verdade que se identifica à noção de uma sinceridade ou autenticidade de todo o grupo $[\ldots]^{33}$
}

Os versos de "Quando ela samba" estão também dotados de uma autenticidade própria que é reconhecida pela comunidade a partir da expressão popular do samba como elemento de distinção do negro (sua identidade) e, ao mesmo tempo, de sua inserção em uma coletividade maior, a que perpassa o caráter brasileiro. Ver a cabrocha sambar ao som do pandeiro é reconhecer seu lugar social como negro e brasileiro. Se nos atentarmos para a data da canção, 1942, podemos entendê-la, nesse sentido, como uma espécie de con-

\footnotetext{
32 "Ganha-se pouco mas é divertido" narra a labuta diária de um trabalhador braçal que tem sua rotina interrompida apenas no domingo, dia de festa no barracão e de samba no morro: "Ele trabalha de segunda a sábado/ Com muito gosto sem reclamar/ Mas no domingo ele tira o macacão,/ Embandeira o barracão,/ Bota a família pra sambar".

${ }^{33}$ MATOS, Claudia. Acertei no milhar, op. cit., p. 32.
} 
cessão do sambista mineiro ao lema ufanista do Estado Novo, que musicalmente teve no "samba de exaltação", criado por Ary Barroso, sua mais completa realização.

\section{MULHER, TRAIÇÃO E DOR EM LUPICÍNIO RODRIGUES}

Quando se trata do exame das letras dos sambas, além da figura do malandro (destacada em vários estudos, dos quais o de Claudia Matos é uma ótima referência), outra que se destaca, como se vê, é a feminina, que tem o papel impulsionador ou inspirador mesmo que esses atributos sejam realizados após algumas decepções no âmbito na vida amorosa. Umas das vertentes do samba que melhor pontuou a mulher como elemento da construção (e da desconstrução) amorosa foi o "samba-canção", também conhecido, sobretudo a partir da poética de Lupicínio Rodrigues, como samba "dor de cotovelo" justamente por relatar o fracasso de uma história de amor.

O samba-canção [...] possuía um discurso mais ou menos padronizado. Em sua grande maioria abordava as aventuras do amor, culminando com a autopunição e desejo de morte. Nada era mais importante que a presença da mulher amada. O poeta, embora sofrendo, quase morrendo de amor, prefere entender tudo, atribuir seu infortúnio ao destino e resignar-se diante da situação. ${ }^{34}$

O "samba canção", em termos musicais, possui ritmo arrastado, suave e bastante melodioso, com menos instrumentos de percussão, sendo, por vezes, orquestrado, mas sem entonação grandiosa do "samba de exaltação". É justo dizer que melodia e letra encenam uma relação afinada, sendo o tom melodioso e arrastado propício para a emanação da tristeza mortuária do eu lírico.

Uma das tópicas da frustração do amor acabado é o sentimento nascente da vingança. Lupícinio soube aproveitar suas experiências e desilusões amorosas para compor as letras de suas canções, sobretudo ressaltando o sentimento de satisfação ao presenciar o ex-amor chorando por sua perda: "Toda vez que uma mulher me trai, eu ganho dinheiro. As mulheres boazinhas nunca me deram dinheiro, só as que me traíram." ${ }^{35} \mathrm{O}$ compositor afirmava que era a partir da dor, do desamor e da traição dessas mulheres que nasciam os maio-

\footnotetext{
${ }^{34}$ CALDAS, Waldenyr. Iniciação à música popular brasileira. São Paulo: Ática, 1985, p. 45.

${ }^{35}$ Disponível no site do musical Vingança, inspirado na obra de Lupicínio Rodrigues.
} 
res sucessos. "Vingança" (1951) tem origem, por exemplo, em uma suposta traição de Mercedez, apelidada de Carioca, mulher com quem Lupícinio viveu seis anos. ${ }^{36}$

Eu gostei tanto,

Tanto quando me contaram

Que lhe encontraram

Bebendo e chorando

Na mesa de um bar,

E que quando os amigos do peito

Por mim perguntaram

Um soluço cortou sua voz,

Não lhe deixou falar.

Eu gostei tanto,

Tanto, quando me contaram

Que tive mesmo de fazer esforço

Prá ninguém notar.

O remorso talvez seja a causa

Do seu desespero

Ela deve estar bem consciente

Do que praticou,

Me fazer passar tanta vergonha

Com um companheiro

E a vergonha

É a herança maior que meu pai me deixou.

Mas, enquanto houver força em meu peito

Eu não quero mais nada

Só vingança, vingança, vingança

Aos santos clamar

Ela há de rolar como as pedras

Que rolam na estrada

Sem ter nunca um cantinho de seu

Pra poder descansar.

${ }^{36}$ Em depoimento, Lupicínio conta a história da canção "Vingança”: "Era época do carnaval, ela [Carioca] endoidou. Botou um Dominó. Dominó é aquela fantasia preta, que cobre tudo. No carnaval, feito louca foi me procurar. Uma certa madrugada, ela, num fogo danado - parece que deu fome - entrou num bar onde a gente costumava comer. Foi obrigada a tirar o Dominó pra comer, e o pessoal a reconheceu. Perguntaram: 'Ué, Carioca, que você está fazendo aqui a essa hora? Cadê o Lupi?' Aí ela começou a chorar. Eu estava num restaurante do outro lado. Uns amigos chegaram e me disseram: 'encontramos a Carioca vestida de Dominó, num fogo tremendo. Começou a chorar e perguntar por ti. O que que houve, vocês estão brigados?' Aí foi que eu fiz o 'Vingança'. Na mesma hora comecei, saiu [canta] 'Gostei tanto, tanto, quando me contaram [...]'." MPB Especial. Lupicínio Rodrigues. Dir. Fernando Faro. São Paulo: TV Cultura, 1972. 
Era natural, para época, que um homem desiludido fosse para uma mesa de bar chorar suas mágoas; mas, aqui, é a mulher quem ocupa esse espaço e desempenha tal papel, inclusive perto dos amigos do eu lírico. A vingança está certamente nisso, na inversão dos valores e dos papéis, pois é o homem quem desconcerta a vida feminina. Em meio a isso, o eu lírico faz acusações: "O remorso talvez seja a causa/ Do seu desespero/ Você deve estar bem consciente / Do que praticou." Não se pode esquecer, entretanto, segundo o próprio depoimento do compositor, que, antes da vingança, houve a libertação feminina através do carnaval e da bebida - o extravasamento feminino, sobretudo em comparação ao do homem, pela ótica moral, não é tolerado. 0 choro é, assim, resultado/punição "do [mal] que praticou" e não estratégia de perdão ou de contenção masculina, como ocorria em "Sem ela", de Herivelto Martins.

A canção termina com o eu lírico, em tom de elevação vocal e instrumental, assumindo o desejo da vingança: "Mas enquanto houver força em meu peito/ Eu não quero mais nada/ Só vingança, vingança, vingança". Sem rodeios e sutileza, o eu lírico condena a mulher a uma perpétua condenação; tudo isso porque não soube acatar a decisão masculina e, em pleno carnaval, "endoidou", conforme revela o próprio Lupicínio Rodrigues.

Em "Se Acaso Você Chegasse", samba-canção de 1938 composto em parceria com Felisberto Martins, Lupícinio observa outro tipo feminino que, se por um lado se assemelha à Amélia de "Ai, que saudades da Amélia (1942), composição de Ataulfo Alves e Mário Lago, mulher domesticada e domesticável; por outro, assume sua sexualidade ao trocar de parceiros e se revelar amante:

\author{
Se acaso você chegasse \\ No meu chateau e encontrasse \\ Aquela mulher que você gostou \\ Será que tinha coragem \\ De trocar nossa amizade \\ Por ela que já lhe abandonou? \\ Eu falo porque essa dona \\ Já mora no meu barraco \\ À beira de um regato \\ $E$ de um bosque em flor \\ De dia me lava a roupa \\ De noite me beija a boca
}


Nesta canção, o eu lírico simulando uma conversa com o ex-companheiro da amada, pleiteia a continuidade da amizade masculina diante do abandono da mulher: "Será que tinha coragem/ De trocar nossa amizade/ Por ela que já Ihe abandonou?". A canção ensaia uma pergunta retórica, pois a mulher "Já mora em meu barraco/ À beira de um regato/ E de um bosque em flor". É interessante pontuar que, aqui, a figura feminina sexualizada sugere, mesmo que o eu lírico não tenha consciência disso ainda, a traição, pois, segundo a ótica moral, ela é capaz de mudar de parceiro - esse dado de consciência pertence ao compositor que optou por contar essa história e não outra, isto é, dois amigos que têm entre eles uma mesma mulher.

Outro aspecto que a canção não revela, mas sugere, é a data de abandono do primeiro parceiro. Dada a amizade entre os dois - o termo "nossa amizade" reforça a temporalidade dos laços —, é certo afirmar que os três se conheciam, sugerindo (com as sutilezas que o compositor de música popular é capaz) a construção de um triângulo amoroso, no qual o último a saber é o "marido traído". Desse modo, a figura feminina vai ganhando ambiguidade a partir de um discurso estrategicamente lacunar, no qual o eu lírico revela (e não revela) a relação amorosa. Parte dessa lacuna se dá pela ausência da voz do "traído".

Outro aspecto interessante nesta figura feminina diz respeito ao modo como ela se assemelha (estranhamente) à saudosa "Amélia", ao aceitar "morar no barraco" e "viver de amor" com o companheiro, caracterizando, assim, o tipo feminino doméstico que, "além do seu despojamento, [mostra] sua capacidade de dar segurança emocional aos homens", segundo observa Ruben Oliven. ${ }^{37}$ Isso porque não é preciso muito para perceber, por meio destes dois versos parafraseados, que a constatação é parecida com a do eu lírico de "Ai, que saudades da Amélia": "Às vezes passava fome ao meu lado/ E achava bonito não ter o que comer/ [...] Amélia não tinha a menor vaidade/ Amélia que era mulher de verdade". Na canção de Ataulfo Alves e Mário Lago, Amélia é contraposta ainda a um outro tipo feminino, aquele que solicita atenção e dinheiro do eu lírico. Longe de se contentar com um barraco bucó-

${ }^{37}$ OLIVEN, Ruben George. A mulher faz e desfaz o homem, op. cit., p. 58. Pontuando a favor da ambiguidade da mulher de "Se acaso você chegasse", está, como dissemos, a sugestão da infidelidade feminina, mostrando-a, nesse sentido, incapacitada a dar "estabilidade emocional ao homem". 
lico "à beira de um regato" e de "viver de amor" e brisa, esta mulher deseja ser tratada com luxo ("Você pensa em luxo e riqueza/ Tudo que você vê você quer"). Em comparação a uma mulher que tem demandas de toda espécie (material ou sexual), Amélia corresponde quase a um ideal feminino, por isso ela pode ser associada, dada a esquematização proposta pelo sociólogo Manoel Berlinck, ao tipo "onírico", "que representa uma mulher inexistente, construída com expressões românticas" ${ }^{38}$. Não é sem razão que o eu lírico da canção se reporta às saudades da Amélia, afirmando, de maneira sutil, sua não existência. Nesse sentido, importa ainda observar que, na canção referida, a personagem presente não é Amélia, mas seu tipo inverso: a que coloca demandas ao homem, que o lembra de seu papel masculino mais básico de provedor e que, portanto, está numa posição também estática ao que diz respeito à imagem feminina.

\section{CONSIDERAÇÕES FINAIS}

O nosso cancioneiro popular, aqui representado por alguns sambas das décadas de 1940-50 de três grandes compositores, apresenta uma imagem feminina bastante variada que, a despeito da esquematização propostas por alguns críticos - reconhecida e válida em algumas análises -, mostra-se dotada de uma ambiguidade particular ao fazer-se, ao mesmo tempo, doméstica e pública, presente e ausente, construtora e desconstrutora quando associada ao universo masculino. Essa mesma mulher que contorna e dá regularidade à vida do homem, pode ser, depois de uma cisão amorosa ou da exacerbação dos desejos femininos, elemento negativo e de entrave emocional, levando-o a uma transformação/decadência moral e física. Nesse sentido, vale destacar o caso de Pedro do Pedregulho, para o qual Estelinha não apenas marca sua inserção na vida doméstica e da ordem, mas também sua morte existencial, simbolizada pela associação do ex-malandro ao mundo de exploração do trabalho alienado. Temos, aí, a mulher como agente desse processo de adequação do homem, negando, em tempos de Getúlio, a vida escorregadia do malandro.

\footnotetext{
38 ibidem, p. 57.
} 